\title{
Identifying Capabilities and Potentials of System Dynamics in Hydrology and Water Resources as a Promising Modeling Approach for Water Management
}

\author{
Ahmed F. Mashaly ${ }^{1,2, *}$ and Alexander G. Fernald ${ }^{1,2}$ \\ 1 College of Agricultural, Consumer and Environmental Sciences, New Mexico State University, \\ Las Cruces, NM 88003-8003, USA; afernald@nmsu.edu \\ 2 New Mexico Water Resources Research Institute, New Mexico State University, \\ Las Cruces, NM 88003-8001, USA \\ * Correspondence: amashaly@nmsu.edu; Tel.: +1-575-741-5054
}

Received: 18 February 2020; Accepted: 4 May 2020; Published: 18 May 2020

\begin{abstract}
Agriculture is the most important sector with regard to water resources management due to its social, economic, hydrological, and environmental aspects, and many scholars and researchers have been driven to investigate the dynamic interrelationships among hydrological, environmental, and socioeconomic factors affecting agriculture. The system dynamics (SD) approach has become widely used because of its merits and benefits as a tool to deal with complex, dynamic problems and systems with many aspects and components that are involved and must be understood to ensure sound decisions regarding water and hydrological systems. Although agricultural water management needs to be studied as a main part of water management, socioeconomic management, and environmental management requiring the use of $\mathrm{SD}$, this review shows that $\mathrm{SD}$ is currently used to a limited extent in terms of agricultural water management. This paper sheds light on the studies and investigations on the use of SD in the water sector and highlights the strengths of SD in order to encourage researchers to use this promising method to manage such a vital resource. Accordingly, this review seeks to include a comprehensive and up-to-date survey of existing publications and scholarly papers on the use of SD modeling as an effective technique for dealing with different problems associated with planning, management, and analysis of hydrology and water resources systems. Recent trends in the integration of SD with other modeling systems, such as artificial intelligence systems, are discussed along with the limitations and challenges facing application. This article makes a new contribution by giving a foundation of references and studies for scholars, researchers, and academics which encourages future investigation in employing the SD approach to hydrology and water resources management and planning, especially with agricultural water.
\end{abstract}

Keywords: system dynamics; agriculture; water resources; hydrology; simulation

\section{Introduction}

Water is at the heart of economic development and is essential for food and energy sustainability, ecosystem integrity, and human life. According to the Food and Agriculture Organization [1], agriculture is the major consumer ( $70 \%$ of all water consumption) of ground and surface water worldwide. The term "agricultural water" broadly describes the water used in agriculture to cultivate and irrigate agricultural field crops, vegetables, fruits, aromatic and medicinal plants, and to raise and conserve livestock, poultry, and fish. Agricultural water also includes water used in applications of pesticides, fertilizers, frost/freeze protection, and cooling of crops. Accordingly, as the backbone of 
agriculture, water must be managed and used in a sustainable, efficient, and balanced manner for sustainable agriculture.

The UN and UNESCO predicted that by 2050, about 5.7 billion people worldwide would face water shortages [2]. Water, in general, is an invaluable economic resource in which it is regarded as a cornerstone in a number of major economic industries such as oil and gas, chemical, petrochemical, electrical and electronics, food, and even healthcare and pharmaceutical industries. Water shortage and scarcity can therefore have a serious effect on agriculture, business, and economic development, and can generate many financial, health, environmental, and ecological problems [3-5]. All of these problems greatly intensify the need to consider and predict the actions and relationship of water resources systems and their consumers. In particular, finding new, quick, and effective management methods for both water, in general, and agricultural water is essential to maintaining and promoting the development of water. Moreover, the investigation and management of water systems needs the integration and adoption of a long-term view of processes and procedures that are hydrological, natural, environmental, and social [6-8]. Therefore, water resources development should usually adopt a systems philosophy and consider dynamic relations among environmental, socioeconomic, natural, and ecological components which are portrayed and described by nonlinear feedback loops [9-12]. Particularly, the management of agricultural water is a complex dynamic process and includes hydrological, natural, and socioeconomic dimensions. Agricultural water also affects strategic sectors such as health, economic development, and poverty alleviation. As a result, agricultural water management should consider these dimensions and factors as well as their interactions and effects in order to better understand complex interrelationships and give a holistic picture of agricultural water.

Many mathematical techniques and models have been proposed to manage these hydrology and water sector interactions. Some have proven useful, yet many water and hydrology models still experience shortcomings regarding methodology, usage, and capacity to comprehensively incorporate the relevant systems $[7,9,13-17]$. The difficulty and uncertainty included in water systems makes their study, analysis, management, and planning an immensely difficult task, especially when using traditional and classical tools. These tools and methods such as regression, work breakdown structures (WBS), critical path method (CPM), or program evaluation and review technique (PERT) are not able to deal with problems of a dynamic nature, such as those with water systems, and do not take into account the interaction between different variables and subsystems, and require a relatively long time and big data to develop models [18-20]. Additionally, traditional modeling methods, such as general multiple regression, are dependent on linear causal reasoning and, thus, cannot introduce the rational and fundamental frameworks needed to face issues at advanced levels of difficulty $[19,20]$. Thus, new tools and techniques are required to face this challenge and address these issues. With advancements in mathematical modeling and computational technology, the usage of system dynamics (SD) with hydrology and water resources could yield results that are not easily obtained with classical and traditional modeling methods using mental model simplifications of the real world through methods such as WBS/CPM/PERT, while SD models can use computing power to capture more complexity $[18,21,22]$.

System dynamics was proposed by Forrester in 1958 [21] for the use of simulating industrial dynamics, and there has been considerable development in the use of SD for understanding, analyzing, managing, and planning of hydrology and water systems in the course of recent decades [23-40]. SD is a technique aimed at examining and analyzing the practices of a system over time by transforming it into associated chains of stocks and flows which influence each other via negative and positive feedback loops. SD methodology tries to analyze and investigate the dynamic connections within whole systems. The strength of SD methodology is its capability to represent the behavior and performance of a system without the need to examine and test the system in advance [16,18,26,31-35]. In addition to saving time and effort, these features make SD's approach able to manage large, diverse, interconnected systems such as water systems in general $[28,33]$ and agricultural water systems in particular. There are currently numerous studies dealing with the application of SD modeling to 
different water management systems and their economic, political, social, environmental, and technical aspects. Although at least one recent paper has reviewed and categorized water and SD [29], there are surprisingly few useful scientific papers that comprehensively review, collect, and compile published studies and research practices in the realm of water resources and SD [36-38], and there is a particular dearth of papers that compile agriculture water and SD studies. To our best knowledge, however, little previous work has holistically used the SD approach to evaluate, plan, and manage agricultural water, such as [12,39,41-43], despite the importance of this vital water resource, which accounts for the largest share of global water consumption and reflects important community and economic realities. Although these few efforts represent beneficial directories for using and applying the SD approach with agricultural water, there is no doubt, however, that there is still a long way to go and that further efforts are required, including new ideas that take advantage of past experiences of SD with water systems in general. Thus, this review paper seeks to fill this gap by addressing multiple objectives and highlighting the importance and technical aspects of the SD approach with a focus on promising applications of the SD method in the water sector that may serve and benefit agricultural water management. It compiles, reviews, and summarizes the objectives, characteristics, and features of previous SD water resources studies and modeling experiments to work as a reference when conducting and implementing SD research for water management, especially in the agricultural sector. This paper allows scientists, modelers, and researchers to quickly identify uses of SD for water and hydrology topics. Beyond serving as a review, this paper seeks to provide useful perspectives for SD modeling applications in the water resources sector and encourage researchers and scholars to use SD for agricultural water applications. By achieving the objectives above, this paper will contribute to opening up new horizons for wide applications of SD in agricultural water management. The approach to this review is as follows. First, it provides a historic overview and analysis of different techniques, types, and applications of water system dynamics models. Second, SD model performance and suitability are assessed as tools for management, analyzing, planning, and evaluation by tracing different developments and applications of SD methodology in the water sector. Third, recent trends to combine system dynamics with other modeling systems, such as artificial intelligence (AI) and geographic information system (GIS), are discussed to ensure the highest levels of accuracy, reliability, and quality in water resource modeling. Fourth, the most important SD software programs used in water applications are provided and analyzed. Last, challenges and limitations of the SD methodology are provided, including concluding remarks and directions for future work.

\section{System Dynamics (SD) Methodology}

SD is a tool for modeling and simulating complex dynamic systems and used to define, analyze, and simulate feedback structures, making it appropriate for simulating and modeling natural, ecological, hydrological, and water systems issues [17,23-25,34,40-50]. Richardson [26] stated that SD is instituted on boundaries and structure, positive and negative feedbacks, and stock (level) and flow (rate). Boundaries are main elements in analyzing systems and central in recognizing the dynamics for determining subsystems [26]. The feedback loop concept is the most important property of SD, which encourages modeling the conduct of problematical issues, mainly when the purpose is to simulate and forecast durable results and attain sustainability [26]. Stock and flows are the cornerstones of SD models, distinguishing overall system status and offering necessary information helping to understand the system and taking appropriate decisions [26]. Stocks are changed by the flows. Stocks are also the foundation for systems decisions and behavior, and can be defined by ordinary differential equations $[23,25,28]$. The mathematical expression of the stock-flow relationship is presented in the following equations [34]:

$$
\begin{gathered}
\text { Stock }(t)=\int_{t s}^{t}[\operatorname{Inflow}(s)-\text { Outflow }(s)] d s+\operatorname{Stock}(t s) \\
d \operatorname{Stock}(t) / d s=\operatorname{Inflow}(s)-\text { Outflow }(s) .
\end{gathered}
$$


where Inflows and Outflows are the inflow and outflow values at any specific time (s) between the original ( $t s)$ and present $(t)$ time [34]. The change rate is the difference between inflow and outflow, and the stock value at time $(t)$ is the stock value at time ( $t s)$ in addition to the integral of difference between inflow and outflow from $t$ to $t$ [34].

To simulate a problem, the system is frequently divided into various spatially and temporally dynamic subsystems which are applied to create a grid of stocks, flows, and feedbacks [41,42,45]. The capability of any SD model to effectively offer a well-organized, precise, and efficient way to simulate a system relies on identifying the key parameters and feedbacks in the system $[10,15,16,32,45-105]$. Many studies have shown that feedbacks are necessary and pivotal for analyzing, assessing, and managing problems related to water issues [43,47,60,74,80,81,85,88,106]. Overall, models using the SD technique are created by building a causal loop diagram (CLD) and transforming it into a stock-and-flow diagram $[22,25,26,34]$. The process of creating SD models commonly begins with goals identification and recognition of modeling parameters and their interactions by means of polarity analysis and dynamic hypothesis, in which the CLD is drawn and the dynamic interactions among the various modeling parameters are hypothesized $[34,59,70]$. It has been found that integration of qualitative and quantitative simulation techniques can considerably improve model effectiveness [34,70]. As a result, an approach for SD modeling has been introduced [59] with the suggested modeling steps $[22,34,35,40,41,58,70,87]$, which are objective determination, polarity analysis, model structure, simulation and theory building.

\section{System Dynamics and Water Systems}

As a useful modeling and simulation technique, SD integrates many hydrological, scientific, scientific, ecological, economic, political, and social variables and parameters into models to find suitable and effective solutions to complex and challenging water resources issues. Employment of SD in analyzing and managing hydrology and water systems has developed over the course of recent decades [25,28,40]. According to Mirchi et al. [29], there are three common approaches to water systems dynamics modeling that can be found: predictive simulation, descriptive, and participatory modeling. It has also been noted in several studies and analysis in recent times that researchers prefer to use other combined SD modeling systems to enhance modeling efficiency and more accurately and clearly define and analyze hydrology and water systems [3,13,67,107-118], and this adds a new SD type. This paper thus deals with four SD types in depth, describing their characteristics and being accompanied by examples. Figure 1 illustrates the four types of different SD models discussed in this study that are used in hydrology and water systems modeling with elaboration of the combined modeling techniques that have been integrated and combined with an SD approach.

There are at least 119 studies and investigations that have explicitly used SD methodology for water resources management, evaluation, analyzing, and planning around the world since 1996. The SD model type has varied in recent studies, with $64 \%$ of the studies using a single descriptive integrated model, $16 \%$ used predictive simulation models, $8 \%$ participatory and shared vision models, and $12 \%$ SD combined with other methods (Figure 2). There has been considerable interest in using SD with water issues over the last 25 years (Figure 3). From 1996 to 2019, the largest number of studies was achieved in 2015, while the lowest number was achieved between 1996 and 2002, at the rate of one paper per year (Figure 3). This indicates a growing trend in the use of systems with water issues.

These studies were carried out to apply SD methodology for the field of hydrology and water resources in different applications in different countries around the world in the period 1996-2019 (Figure 4). The country was determined based on the case study addressed in each paper. The United States and China lead the list of countries in the use of SD modeling techniques in research on water issues with a total of 50 published papers (42\%), as indicated in Figure 4. In Canada and Iran, SD has also been considerably used for modeling different water issues and applications. In general, many water issues and problems have been addressed, as detailed below. 


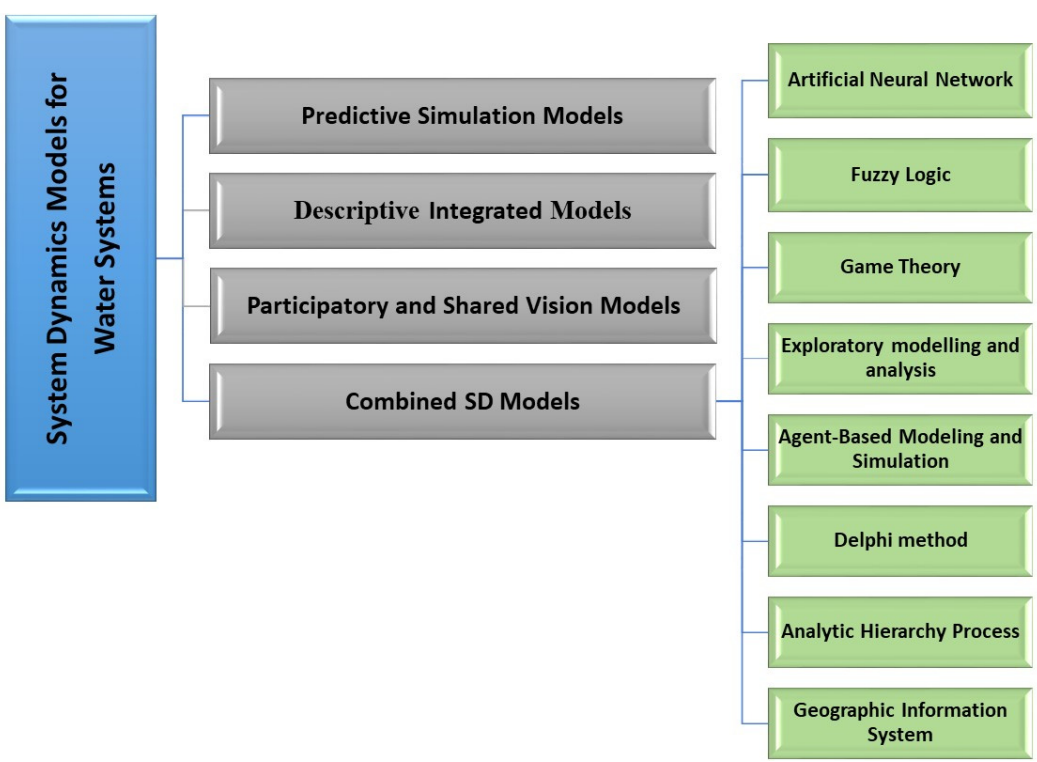

Figure 1. Types of system dynamics (SD) models used in water systems modeling.

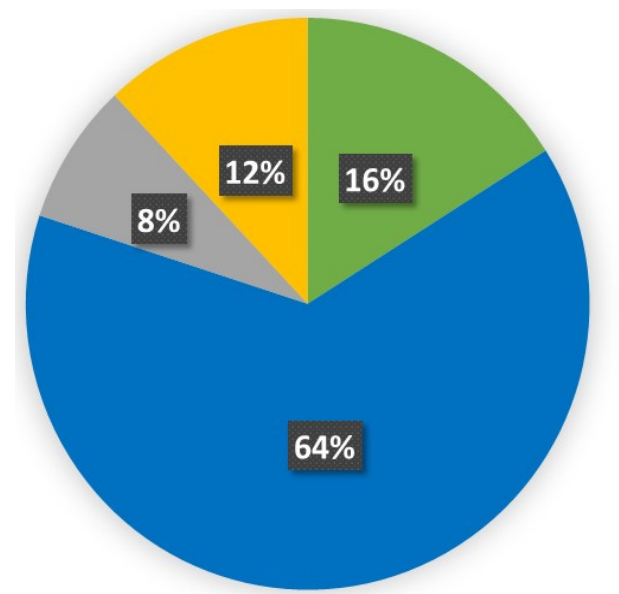

- Predictive Simulation Models

- Descriptive Integrated Models

- Participatory and Shared Vision Models

- Combined SD Models

Figure 2. Percentage of usage of the system dynamic model types within the water sector in recent studies.

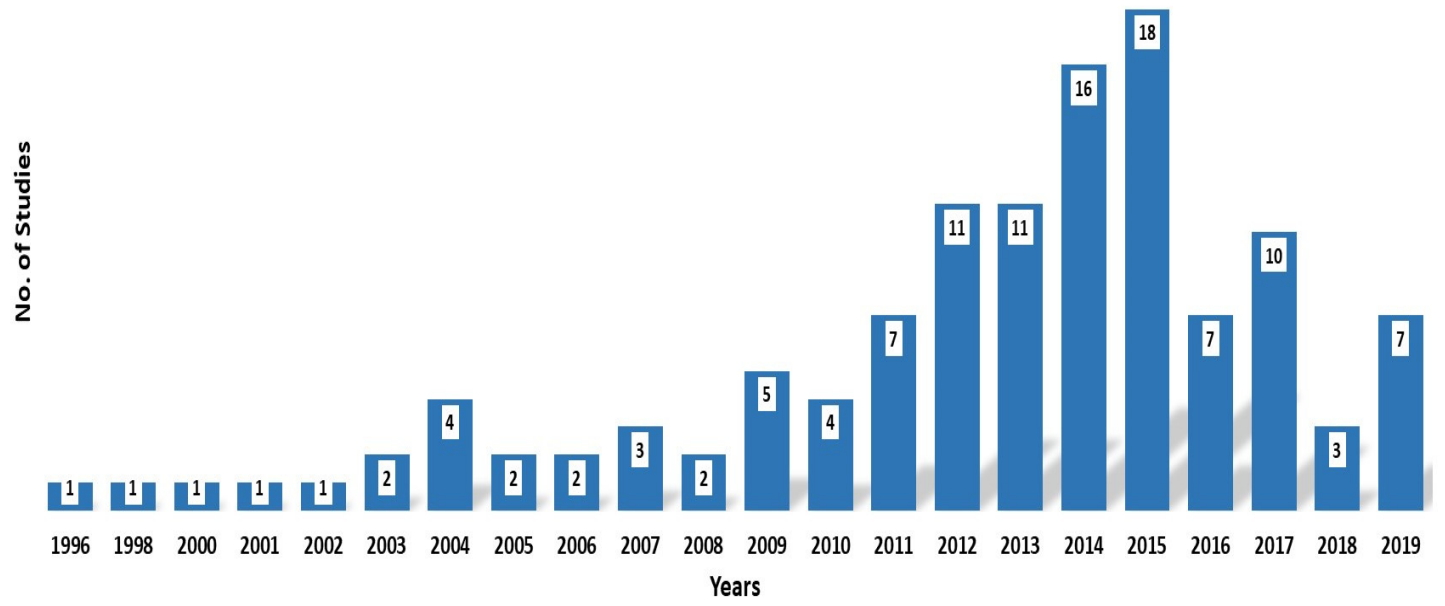

Figure 3. Studies of system dynamics models in water and hydrology sector during the years 1996-2019. 


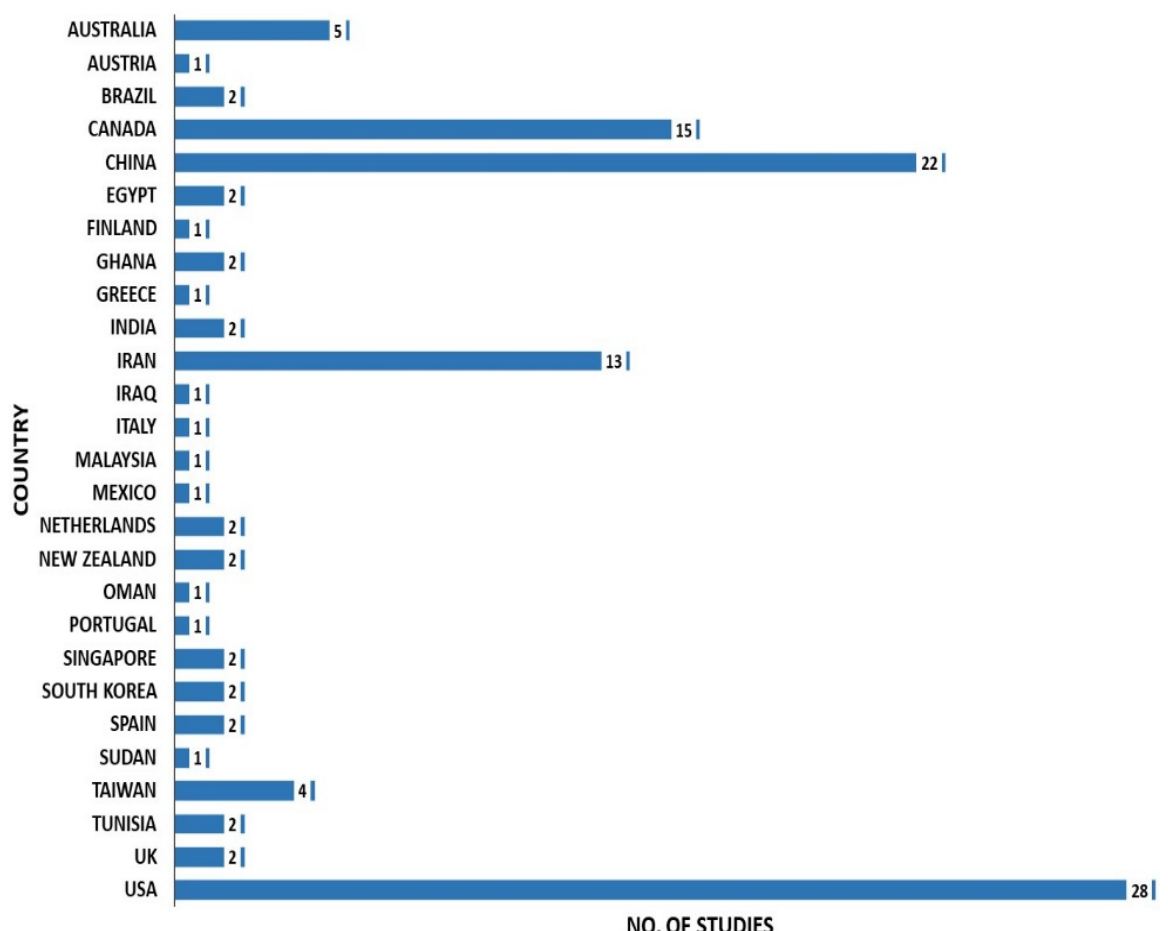

Figure 4. Number of system dynamics studies related to hydrology and water resources in various countries during the years 1996-2019.

\subsection{SD Potential in Water Predictive Simulation Models}

Predictive simulation models use SD methodology to model systems based on historical performance data and to use the calibrated and validated model to extrapolate or predict the effects of water problems and issues in the future $[13,30,45,46,50]$. Predictive simulation models have been used and utilized with many water and hydrology issues covering hydrologic cycle modeling, aquifer and groundwater modeling, river basin modeling, irrigation water modeling, hydropower generation modeling, ecological modeling, and water quality modeling in many different regions of the world $[30,52,57,58]$. The capabilities of the predictive simulation models have been reliable in improving the prediction of water availability, flood management, and climate change impacts, which improves the resilience of agricultural water systems and enables more detailed water management interventions to reduce production risks $[51,53,56,57]$. The capability to investigate different feedbacks, interactions, and predictions helps researchers to increase the precision of developed models for water systems and decrease the number of modeling variables, as many studies published in this field have shown [55-57].

SD methodology with predictive simulation models is a suitable simulation tool for examining hydrology and water resources problems as well as watershed processes such as flooding $[13,45,46]$. One of the most dynamic predictive issues addressed is flood management because of its importance in flood control, forecasting and mitigation, and understanding the development of flooding and related factors. For instance, Ahmad and Simonovic [45] applied the SD approach to demonstrate hydrologic cycle components for reservoir operations and flood management. Influences on reservoir's flood capacity are investigated by modeling gated and unregulated spillways. The developed model can be expanded from one reservoir to a series of reservoirs considering different inflows and outflows. The smooth modification of the model to test the expected changes and the high capability to conduct sensitivity analysis makes this approach effective. Simonovic and Li [46] used an SD model in creating flood system evaluation methodology. The SD model used is dependent on flood flow levels and flood capacity at various points in a river basin system. The outcomes showed that the ability of the current flood protection procedure is adequate and suitable under conditions of future climate 
change fluctuation. Ahmad and Simonovic [13] introduced a new technique called spatial SD to model feedback impacts and dynamic interactions governing flood reproduction. The suggested approach was successfully utilized in flood management and assessing floodway operation considering spatial variability and different parameters such as depth, extent, and discharge of flooding. Based on the above, it is clear that SD modeling is a suitable simulation tool for examining hydrology and water resources problems and watershed processes such as flooding. In addition to those mentioned, listed below in Table 1 are a few more examples and studies of predictive simulation models that have been successfully applied in the water and hydrology sector.

Table 1. Examples of predictive simulation SD models used with different water problems.

\begin{tabular}{|c|c|c|c|}
\hline Application & References & SD Modeling Objectives & Results with the SD Method \\
\hline $\begin{array}{l}\text { Groundwater } \\
\text { and aquifer } \\
\text { modeling }\end{array}$ & [52-55] & $\begin{array}{l}\text { Using SD for groundwater flow, } \\
\text { hydraulic redistribution, groundwater } \\
\text { storage, and sustainable aquifer } \\
\text { management. }\end{array}$ & $\begin{array}{l}\text { Influences of climate change and } \\
\text { water use on spatial and temporal } \\
\text { differences in groundwater flow, with } \\
\text { insights for management and policy. }\end{array}$ \\
\hline $\begin{array}{l}\text { Hydroelectric } \\
\text { power } \\
\text { evaluation }\end{array}$ & {$[56,58]$} & $\begin{array}{l}\text { Hydropower and hydraulically } \\
\text { reservoir regime modeling. }\end{array}$ & $\begin{array}{c}\text { Hydrologic influences and impacts on } \\
\text { hydroelectricity production, with } \\
\text { performance measures to quantify } \\
\text { multi-reservoir regimes. }\end{array}$ \\
\hline $\begin{array}{l}\text { Water } \\
\text { quality } \\
\text { assessment }\end{array}$ & $\begin{array}{l}{[30,44,50,51} \\
57,119]\end{array}$ & $\begin{array}{l}\text { Simulating water quality, total } \\
\text { maximum daily load, salinity, } \\
\text { treatment, vegetation cover, } \\
\text { and eutrophication. }\end{array}$ & $\begin{array}{l}\text { Water quality control, increased } \\
\text { environmental functions, and urban } \\
\text { planning to improve water quality } \\
\text { and reduce salinity impacts. }\end{array}$ \\
\hline
\end{tabular}

\subsection{SD Potential in Water Descriptive Integrated Models}

The current literature in SD recognizes major feedback loops in descriptive integrated models of water and hydrology systems [10-12,17,39,56-62], and it includes topics related to social, economic, and hydrological modeling [77,81-83]. By using descriptive integrated models, scholars and modelers have embraced a comprehensive method that aims to find and describe the feedbacks for different systems, such as ecological, environmental, social, political, hydrological, and economic systems. In fact, many of the latest SD uses in water and hydrological systems belong to descriptive integrated models $[17,39,56-62,66]$, and address topics related to social, economic, and hydrological modeling. Descriptive integrated models can be used for integrated modeling of water resources, and this is due to the fact that integrated modeling of a water resources system involves many facilities, clarifications, and simplifications for various nonlinear relationships and feedbacks between several subsystems. Descriptive integrated models present many advantages that have made it a common simulation tool for integrated water resources planning, analysis, and management. The following sections review several hydrology and water resources systems studies and investigations using SD methods to define and analyze the feedback structure and behavioral trends of water descriptive integrated models.

Descriptive integrated models have been employed to help specify, study, and understand what the sociohydrology system is, what it does, and how it does this. For example, Di Baldassarre et al. [77] proposed an SD methodology for expressing feedbacks and interactions among sociohydrology processes to recognize the internal relationships of the human-flood system and the influence of changing individual characteristics, and found SD is capable of reproducing reciprocal impacts between floods and humans. The challenges in hydrological and socioeconomic processes have been overcome by developing a dynamic perception for floodplains and considering them to be associated with human activity. Maxwell et al. [81] introduced a comprehensive SD approach for simulating hydrosocio-environmental processes, interactions, and feedbacks for reducing the resulting effects of sediment transport, drought occurrence, and floods risk in an arid environment. A water budget methodology was employed as the cornerstone for the developed model, which simulates groundwater recharge and stormwater reuse and illustrates the strategies needed for managing stormwater runoff 
and groundwater storage. The findings demonstrated the importance of management strategies and trade-offs in managing watershed restoration and soil water storage.

Additionally, descriptive integrated models have been used with water applications related to hydrologic-socioeconomic aspects. For instance, Karamouz et al. [83] presented a comprehensive economic framework using SD methodology of every possible profit and expense emerging from current actions, procedural applications, and application of procedures and policies for a basin plain. The costs involved in modeling process are capital and operating costs, crop production costs, pumping costs, and ecological costs. The study provides a general framework for evaluating the administrative policies of water resources, taking into account the economic and environmental interactions, their overlaps, and their implications for crop productivity, cultivated areas, and water efficiency. The SD's results showed how merging many techniques and methods alongside an economic structure could successfully help stakeholders to know the outcomes of an applied policy on water resources. De Stercke et al. [17] developed an SD model with a clear demonstration of the water-energy nexus of domestic application and consumption and their effect on future demand in London, UK. The proposed methodology is based on a climate change mitigation policy and involves reducing demand via price. It covers water systems and their capacity and supply. Interactions and interferences among water supply, demand, available sewage system, energy intensity, and their implications for water resources scarcity have also been taken into account. The findings revealed a conspicuous need in policy evaluation to consider the water-energy nexus. This methodology can be used efficiently with the overlapping and branched economies found in industrialized countries. Langarudi and his colleagues [43] introduced an SD model to investigate the effect of water use dynamics on the agriculture, population, and economy along with their feedbacks for lower Rio Grande (LRG) region in New Mexico, USA. The developed LRG model is an offshoot model that acts as an extension to the New Mexico dynamic statewide water budget model (NMDSWB) that uses a mass balance methodology to assemble monthly water storages and flows for counties, water planning regions, river basins, and statewide in New Mexico [120]. Seven subsystems represented the developed LRG model, namely hydrology, water use, agricultural production, non-agricultural production, wage, labor, and population. The results showed that the model offered an important starting point for any attempt at modeling the sociohydrology. The authors concluded that in water modeling issues, it is important to evaluate the effect of socioeconomic parameters such as population, economic output, and irrigated area.

There are several research advances and applications illustrating and explaining the importance of integrated descriptive models using SD in the water and hydrological field. For example, Liu et al. [82] described the development of a model-based SD approach able to precisely simulate the economic growth, resource consumption, and ecological influences in Beijing, China. The dynamic model was mainly based on hydrological, economic, demographic, and environmental parameters. The methodology used lists the expected negative impacts on human welfare, environmental safety, and urban development. Statistical evaluations, calibrations and validations, along with dynamic interactions and feedbacks, will help support different required policies, scenarios, and analyses. The model showed that water is the dominant component of the sustainable development process. The results of their SD model will enable policymakers to understand interactions and impacts on urban development and economic growth. Wang et al. [88] developed integrated SD-based methodology for managing water resources considering water supply and demands as well as different socioeconomic and environmental scenarios. A new index has been generated to assess the various interactions based on water balance, and this creates a complete and strong representation of river basin environment. The results of the various trade-offs have shown and contributed to the development of a general vision of water security in the river basins, which has helped to develop the performance of integrated management of water resources and pave the way for the concept of the water sustainability in basins. Additionally, Table 2 demonstrates some of the different issues and applications of water descriptive integrated models. 
Table 2. Examples of issues and applications of descriptive integrated SD models used with different water problems

\begin{tabular}{|c|c|c|c|}
\hline Application & References & SD Modeling Objectives & Results with the SD Method \\
\hline $\begin{array}{l}\text { Groundwater } \\
\text { modeling }\end{array}$ & $\begin{array}{l}{[7,11,61,75} \\
121,122]\end{array}$ & $\begin{array}{l}\text { SD modeling for treating uncertainty with integrated } \\
\text { hydroeconomics, considering the mutual relations among } \\
\text { accessibility and growing uses of water, investigating groundwater } \\
\text { dynamics under various economic conditions and studying } \\
\text { hydrologic and socioeconomic relationships of groundwater balance. } \\
\text { Developing a model for evaluation of groundwater polices. }\end{array}$ & $\begin{array}{l}\text { The developed methodology effectively analyzed the effects of } \\
\text { different management techniques, water stress, aquifer dynamics, } \\
\text { economic behavior, area climatology and economic policies and rising } \\
\text { groundwater withdrawal. The results showed the best strategies and } \\
\text { scenarios for efficient groundwater management and decision-making } \\
\text { related to this vital water resource. }\end{array}$ \\
\hline $\begin{array}{l}\text { Surface } \\
\text { water } \\
\text { management } \\
\text { modeling }\end{array}$ & $\begin{array}{l}{[12,15,39,40} \\
58,63,66,123 \\
124]\end{array}$ & $\begin{array}{l}\text { Comprehensive SD approach for managing for the lake basin, } \\
\text { evaluating the river system, and investigating reservoir balance } \\
\text { considering hydrological and socioeconomic parameters. }\end{array}$ & $\begin{array}{l}\text { The results showed the different positive aspects of SD in accurately } \\
\text { understanding and expressing water demand, water supply, } \\
\text { hydroelectricity generation, human-water systems, and climate } \\
\text { change based on different scenarios and conditions. Assessments of } \\
\text { population change effect, agricultural demand, and production and } \\
\text { irrigation impacts for water, economic, energy, and food concerns } \\
\text { using feedback processes and interactions were clearly demonstrated. }\end{array}$ \\
\hline $\begin{array}{l}\text { Holistic } \\
\text { water } \\
\text { resources } \\
\text { management }\end{array}$ & $\begin{array}{l}{[10,14,60,68} \\
69,71-73,76 \\
79,95,97,119 \\
125-128]\end{array}$ & $\begin{array}{l}\text { Presenting sociohydrological models based on SD methodology for } \\
\text { integrated water management. Considering different parameters } \\
\text { and subsystems such as population, demographic extension, water } \\
\text { supply-and-demand, economic development, climatic conditions, } \\
\text { water sustainability and water balance. }\end{array}$ & $\begin{array}{l}\text { The developed model determined the socioeconomic, environmental, } \\
\text { natural and ecological changes and impacts on water management. } \\
\text { The results are used to identify and understand the potential for } \\
\text { feedbacks between social and hydrological systems. This greatly helps } \\
\text { in sustainable water management. }\end{array}$ \\
\hline $\begin{array}{l}\text { Water } \\
\text { scarcity and } \\
\text { shortage } \\
\text { simulation }\end{array}$ & {$[8,74,93]$} & $\begin{array}{l}\text { Using SD methodology to study water scarcity and alleviating water } \\
\text { shortages based on the dynamics of sociohydroeconomic processes. }\end{array}$ & $\begin{array}{l}\text { The developed conceptual models were accurate in showing } \\
\text { interactions and integrating several subsystems. The obtained findings } \\
\text { were effective in assessing different water policies analytically and } \\
\text { quantitatively. The urban expansion index and the feedbacks among } \\
\text { human, ecological, and hydrological systems were analyzed, and their } \\
\text { importance for understanding water scarcity shown. }\end{array}$ \\
\hline $\begin{array}{l}\text { Water } \\
\text { desalination } \\
\text { and } \\
\text { treatment }\end{array}$ & $\begin{array}{l}{[62,80,92,} \\
129]\end{array}$ & $\begin{array}{l}\text { Introducing SD methodology for combining hydrological, economic, } \\
\text { social, and technical scenarios and polices to analyze different } \\
\text { dimensions of desalination and treatment processes. }\end{array}$ & $\begin{array}{l}\text { They illustrated and demonstrated that desalination provides a } \\
\text { feasible, practical, and safe water supply alternative. The results help } \\
\text { to understand the relationship between water availability and use and } \\
\text { will be a benefit in the processes of formulating water supply policies. }\end{array}$ \\
\hline $\begin{array}{l}\text { Acequia } \\
\text { (Irrigation } \\
\text { canal) } \\
\text { Modeling }\end{array}$ & {$[41,47,130]$} & $\begin{array}{l}\text { Providing SD methodology for integrating hydrology, economic, } \\
\text { social, environmental, and natural systems in acequia areas. } \\
\text { The challenges in conventional irrigation communities have been } \\
\text { described and analyzed in a dynamic way based on feedbacks. }\end{array}$ & $\begin{array}{l}\text { The results indicate the ability of system dynamics to express the } \\
\text { various interactions and feedbacks in acequias, as well as the } \\
\text { important role of relations and links between natural and human } \\
\text { systems and provide a solid basis for economic and political modeling } \\
\text { of acequias in the future. }\end{array}$ \\
\hline
\end{tabular}


Ultimately, descriptive integrated methodology can be effectively applied to create models that can simulate and make predictions for a wide range of hydrological, environmental, ecological, economic, and political parameters. It is clear to us through all these reviewed studies that descriptive integrated modeling is efficient in water problems associated with social, economic, ecological, or environmental impacts. With increased attention to studying the sociohydrological aspects, as stated earlier, several researchers have used descriptive integrated modeling approaches to establish comprehensive sociohydrological models. SD-integrated models are able to cover a variety of components and subsystems and perfectly simulate interactions among several variables and parameters. The effectiveness of such a modeling method, in which the researcher should have sufficient know-how to create an integrated model covering all aspects, causes, variables, parameters, inputs, and relationships between external and internal and dynamic effects, must be taken into account. The value of using descriptive integrated models of agricultural water management is to ensure the correct balance of agriculture, climate, and water systems for resources sustainability without any environmental, economic, and social changes adversely affecting the agricultural sector's efficiency.

\subsection{SD Potential in Water Participatory and Shared Vision Models}

Participatory and shared vision modeling is the approach of integrating stakeholders, community, and decision makers in an analytical modeling process to assist critical decisions related to hydrology and water resources. SD modeling has been utilized as an effective way for boosting shared vision planning and learning modeling by different stakeholders in the water sectors [98-100]. Participatory and shared vision models support the process of the joint comprehension of a water and hydrological systems and enhance the social, economic, ecological, and environmental aspects of water management policies and decisions by engaging policymakers and stakeholders. Decision makers' involvement in the modeling process promotes understanding of the problem and its different aspects, increases confidence in the results obtained, supports the chosen strategies and provides a strong modeling framework for water resources systems $[10,131,132]$. There are many examples of participatory water resources modeling employing system dynamics. However, some studies which address and discuss participatory modeling of water resources systems using SD methodology are presented in the upcoming section.

Many researchers and scholars have used SD as participatory and shared vision models in the water sectors. For example, Ford [102] designed a computer simulation model based on an SD approach for the Snake River, US. The model simulates the annual flows in the Snake River at major points of importance for agrarian groups, ecology groups, and the power industry. The proposed model also shows problems related to water rights and falling water levels and can be used to check the possible solutions to resolve these problems. Karamouz et al. in Iran [103] proposed an SD dispute resolution model for monthly allocation of waste in river systems, where stakeholders and decision makers take into account their relative authorities and address the expectations and dissatisfactions with one another. Spatial and temporal variations were considered in the developed SD model which offers a good solution for assessing water quality. The findings demonstrated that the developed model can successfully incorporate the preferences of the stakeholders and decision makers in providing a final agreement.

Kotir et al. [106] presented participatory and methodological processes contributing to creating an SD model to support integrated water resources management, environmental development, and sustainable agricultural development. The proposed model offers a detailed understanding of the principal biophysical and socioeconomic elements and processes in the Volta River Basin, West Africa. Assessing the SD findings obtained from a stakeholder perspective has helped to comprehensively evaluate various feedbacks and interactions of the water resources in the basin. Additionally, participatory and shared vision models have been utilized for an extensive variety of water applications and modeling, including public water management [131], community-based water planning [132], water supply and demand [101], river basin management [99], aquifer dynamics [100], wetland modeling [6], 
hydrological, environmental and socioeconomic systems [104], and drought management [105]. It is evident from the above articles that participatory and shared modeling can be used for a range of purposes, including decision support, information management, and forecasts of complex and difficult water systems for modelers, researchers, and policymakers. Participatory and shared modeling is mainly consistent with the growing focus on comprehensive water resources management, which includes systems theory and takes into account economic, social, and environmental parameters. Multiple water problems have been widely and successfully studied with participatory and shared vision models, such as watershed management, surface and groundwater planning, drought management, water conflict, and climate change. It is clear to us that participatory and shared models have become of great importance due to the complexities of the water systems and their urgent need to incorporate various efforts to create an effective vision that serves all parties and takes environmental, economic, and social aspects into consideration.

\subsection{SD Potential in Water Combined Models}

Combining SD methodology with other modeling approaches helps to analyze, represent, and understand complicated and difficult problems, issues, and systems as well as to discover potential solutions and policies. Although SD modeling has important advantages, it is unavoidably subject to some limitations. In addition, SD cannot find the perfect choices, outcomes, and solutions on its own. Modeling uncertainty using SD is a daunting task, and modeling processes in the case of spatially distributed data [13,108-110] will be difficult. Many studies and investigations have illustrated that SD modeling of complex problems can be improved by integrating with other modeling procedures and methods. One of the benefits of combination is the ability to deal comprehensively with water problems and issues and to draw stronger conclusions than standard or usual SD methods [5,111].

Generally, SD modeling can be employed to combine descriptive and numerical parameters of a complex circumstance. There are six stages and phases by which SD modeling methodologies are combined and incorporated with other approaches and techniques. The first step, according to Sterman [34] and Zolfagharian et al. [110], is to identify the initial problem, which allows researchers to know if SD can be used to solve the problem. The second stage involves analyzing the issue in terms of kind, the key parameters, and their causal relationships. The third step deals with why a specific combination should be acceptable. The fourth step is the way the intended combination is actually implemented. The fifth step is to get the combined model, while in the sixth step, it is assessed and strengthened. As a result, several researchers have suggested combining SD with other water sector simulation, modeling, or optimization techniques. Nevertheless, given the abundance of literature on the combination method, there is no simple and concise study, description, or review of when and how SD is combined with other techniques, or findings of different combinations used for water land issues and uses. The key reasons for combining the SD technique with other approaches can be illustrated in the water problem, its complexity and multiple levels, the difficulty in formulating causal relationships, and the variability and ambiguity of the causes, variables, and parameters involved. Table 3 shows combined system dynamics models in some studies and their modeling objectives, results, and findings.

This review found that SD approaches have been successfully combined with many other modeling techniques (Table 3). In short, there is promise for combined systems because of the great benefits derived from the combination process, summed up as improving SD's ability to express the water problem clearly, increase the confidence and accuracy in the modeling process, and incorporate new features and characteristics of water and hydrological models. 
Table 3. Some studies for combined system dynamics models in the water sector.

\begin{tabular}{|c|c|c|c|}
\hline Combined Method & References & Modeling Objectives & Results and Findings \\
\hline $\begin{array}{l}\text { Geographic } \\
\text { Information System } \\
\text { (GIS) }\end{array}$ & [13] & $\begin{array}{l}\text { Introducing a new SD and GIS-based method for } \\
\text { spatiotemporal simulation of flood damage } \\
\text { assessment processes. }\end{array}$ & $\begin{array}{l}\text { The new methodology can be employed to model an assortment of } \\
\text { hydrological and environmental parameters, and consider space-time } \\
\text { interaction, for example, in water resources processes and } \\
\text { catastrophe management. }\end{array}$ \\
\hline Impact Analysis (IA) & [3] & $\begin{array}{l}\text { Suggesting a process for combining SD method and IA } \\
\text { to assess water strategy methodically and quantitatively } \\
\text { and formulating a suitable approach to examine an } \\
\text { equilibrium among alleviating water scarcities or } \\
\text { shortages and capital expenditure. }\end{array}$ & $\begin{array}{l}\text { The suggested model could be used to understand the interactive } \\
\text { influence between the intensity of water shortage and financial spending } \\
\text { for planning water demand in the future. In central Taiwan, } \\
\text { the usefulness of the suggested approach is successfully checked by } \\
\text { solving a water scarcity problem and total expense. }\end{array}$ \\
\hline $\begin{array}{l}\text { Agent-Based } \\
\text { Modeling and }\end{array}$ & [113] & $\begin{array}{l}\text { Comparing and analyzing SD and ABMS techniques } \\
\text { and determining the potential interfaces to build }\end{array}$ & $\begin{array}{l}\text { They concluded that the SD-ABMS approach is considerably and } \\
\text { effectively suitable with modeling issues such as that in }\end{array}$ \\
\hline Simulation (ABMS) & & effective expert systems. & sociohydrological models. \\
\hline $\begin{array}{l}\text { Artificial } \\
\text { Intelligence (AI) and } \\
\text { Agent Based } \\
\text { Modeling (ABM) }\end{array}$ & [114] & $\begin{array}{c}\text { Developing a novel sociotechnical modeling approach } \\
\text { to investigate the relationships between socioeconomic } \\
\text { environment and hydrologic unit using SD, AI, } \\
\text { and ABM methods. }\end{array}$ & $\begin{array}{l}\text { The developed methodology takes into account the socioeconomic } \\
\text { parameters to be involved in the evaluation of awareness-raising } \\
\text { campaigns for hydrological systems. This study also provides a detailed } \\
\text { demonstration for the urban water resources cycle. }\end{array}$ \\
\hline \multirow{2}{*}{$\begin{array}{l}\text { Exploratory } \\
\text { Modeling and } \\
\text { Analysis (EMA) }\end{array}$} & [115] & $\begin{array}{l}\text { Offering an approach for studying and analyzing the } \\
\text { challenges to freshwater management using innovative } \\
\text { SD and EMA techniques and presenting a methodology } \\
\text { for a coastal area relies on groundwater to analyze a } \\
\text { saline water intrusion problem. }\end{array}$ & $\begin{array}{l}\text { In a decision tree, the results are discussed to help enforce the correct } \\
\text { approaches and policies for the analysis and management groundwater } \\
\text { in coastal areas. The research will help clarify the future path of } \\
\text { population growth, economic activities, agricultural systems, } \\
\text { and techniques for water purification for coastal aquifers management. }\end{array}$ \\
\hline & [116] & $\begin{array}{l}\text { Exploring and studying the limits on global use of } \\
\text { freshwater. Identifying the best and worst water stress } \\
\text { conditions and world population development using a } \\
\text { combination of SD and EMA. }\end{array}$ & $\begin{array}{l}\text { The authors demonstrated that under extreme water stress or restricted } \\
\text { population growth the global water usage can be effectively studied and } \\
\text { evaluated using the developed methodology. }\end{array}$ \\
\hline \multirow{2}{*}{$\begin{array}{l}\text { Analytic Hierarchy } \\
\text { Process (AHP) }\end{array}$} & [67] & $\begin{array}{l}\text { Combining SD and AHP to develop a simulation model } \\
\text { and an assessment index system for the local water } \\
\text { environmental carrying capacity. }\end{array}$ & $\begin{array}{l}\text { The findings of this investigation could be used for developing } \\
\text { socioeconomic solutions and addressing hydroecological problems. }\end{array}$ \\
\hline & [117] & $\begin{array}{l}\text { Proposing new integrated decision support model } \\
\text { based on the synergy of SD and AHP techniques for } \\
\text { relieving the dangers of urban flooding. }\end{array}$ & $\begin{array}{l}\text { They concluded that this innovative approach could be used for many } \\
\text { other related issues around the world where decision makers and } \\
\text { policymakers need to make strategic decisions that have significant } \\
\text { long-term consequences for water and hydrological systems. }\end{array}$ \\
\hline
\end{tabular}


Table 3. Cont.

\begin{tabular}{|c|c|c|c|}
\hline Combined Method & References & Modeling Objectives & Results and Findings \\
\hline Fuzzy Logic (FL) & [109] & $\begin{array}{c}\text { Presenting the SD technique coupled with FL for } \\
\text { analyzing flood risk. }\end{array}$ & $\begin{array}{l}\text { The novel model demonstrated to be a precise method for forecasting } \\
\text { spatiotemporal difference of water elevation for flood risk management } \\
\text { and evaluation. }\end{array}$ \\
\hline \multirow{2}{*}{$\begin{array}{l}\text { Bayesian Network } \\
\text { (BN) }\end{array}$} & [118] & $\begin{array}{l}\text { Introducing a methodology to support decision making } \\
\text { based on the approaches of SD and BN for the } \\
\text { management of groundwater-agricultural systems. }\end{array}$ & $\begin{array}{l}\text { The key purpose of this study was to incorporate hydrological and } \\
\text { socioeconomic relations and to address the problems and difficulties of } \\
\text { reconciliation between sustainable aquifer management and productive } \\
\text { agricultural yield. }\end{array}$ \\
\hline & [111] & $\begin{array}{l}\text { Developing an incorporated model dependent on a } \\
\text { combination of SD with BN to simulate and analyze } \\
\text { water quality. }\end{array}$ & $\begin{array}{c}\text { The outcomes show the developed methodology could offer decision } \\
\text { making tool for watershed management to avert water } \\
\text { quality impairments. }\end{array}$ \\
\hline $\begin{array}{l}\text { Neural Network } \\
\text { (NN) }\end{array}$ & [5] & $\begin{array}{c}\text { Water scarcity analysis and modeling using SD and NN } \\
\text { methods to explain how environmental, ecological, } \\
\text { and social parameters influence water demand and } \\
\text { supply. }\end{array}$ & $\begin{array}{l}\text { The results give us an overview of how water supply and demand can } \\
\text { be changed. Water scarcity was successfully estimated and predicted, } \\
\text { and using the suggested approach, the most influential elements such as } \\
\text { precipitation, population, and runoff were identified. }\end{array}$ \\
\hline Game Theory (GT) & [107] & $\begin{array}{l}\text { Introducing modeling methodology based on an } \\
\text { integration of SD with GT for water conflict resolution. }\end{array}$ & $\begin{array}{l}\text { The developed model is able to help in addressing water conflict in the } \\
\text { river systems and showed a high capability with complexity and } \\
\text { uncertainty conditions in the hydrological systems. This approach is also } \\
\text { fairly simple to use when assessing and managing essential water } \\
\text { resources. This provides all the priorities and choices for stakeholders } \\
\text { and decision makers on water resource systems management } \\
\text { and planning. }\end{array}$ \\
\hline
\end{tabular}




\section{System Dynamics Software Packages used in Water and Hydrological Sectors}

One of the success criteria of the SD modeling process is the appropriate and proper selection of software used in the development of the SD model [131-140]. However, numerous modeling packages have been developed to ease structuring and implementing SD models in different fields such as AnyLogic, DYNAMO, Exposé, Forio, IThink/Stella, MyStrategy, Powersim, Simile, True, MapSim, and Vensim. Through the review of various publications and papers related to the application of $\mathrm{SD}$ in the water sector, the most used software packages are Vensim, IThink/Stella, and PowerSim. More information on these packages is listed in Table 4. In general, these packages are simple to use and provide a diversity of functions and offer optimization and validation techniques. Moreover, they boost cooperative modeling and connection with very large datasets. According to our review, the largest number of studies and research was carried out using Vensim software by $52 \%$ of the total studies in the field of water, while the IThink/Stella software was used in about $39 \%$ of all studies (Table 4). Only 9\% of the total studies were conducted using PowerSim, and this may be due to the fact that PowerSim is more suitable for business solutions, and requires more experience and has a higher cost compared to Vensim and IThink/Stella packages.

Table 4. System dynamics software packages commonly used in the water sector.

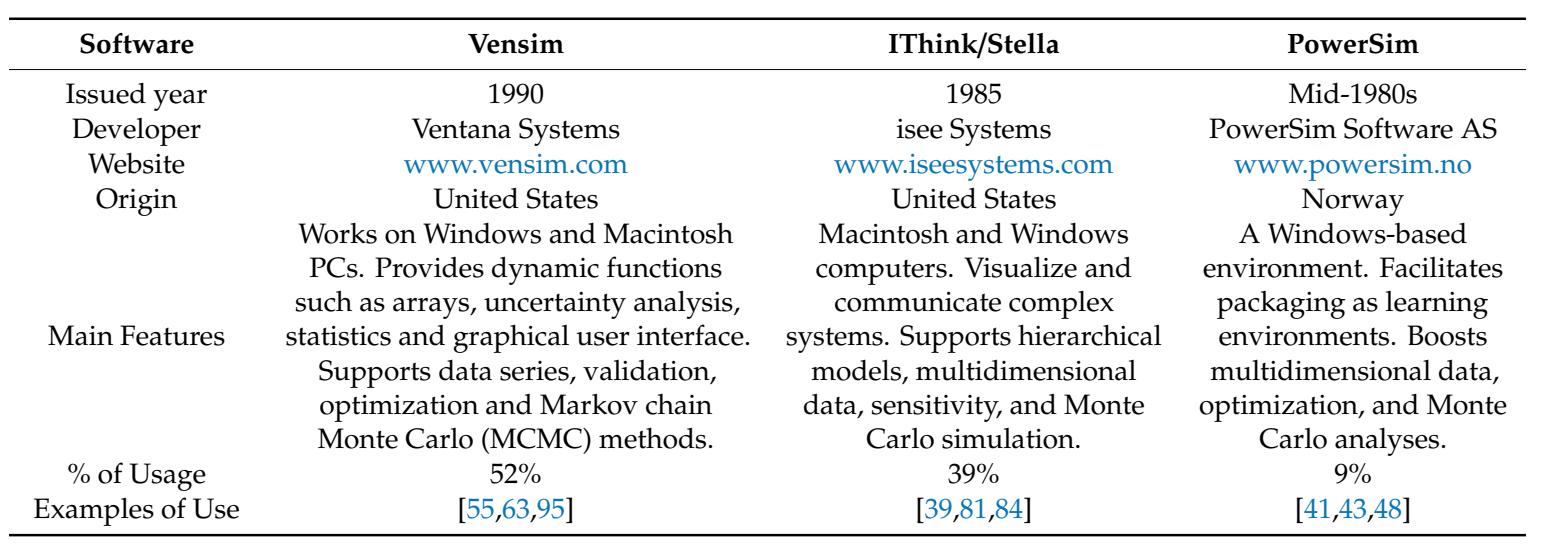

\section{Challenges and Limitations of System Dynamics}

It is evident from the above that many researchers and modelers performed extensive studies on water issues and water systems and achieved substantial outcomes and progress using SD approach. Even though there is much research and experience, there are still some difficulties, constraints, and challenges that limit the comprehensive use of the SD modeling approach in issues related to and specialized in water resources systems. We can summarize the challenges and limitations facing SD with water applications as presented in Figure 5, and each challenge is explained separately below.

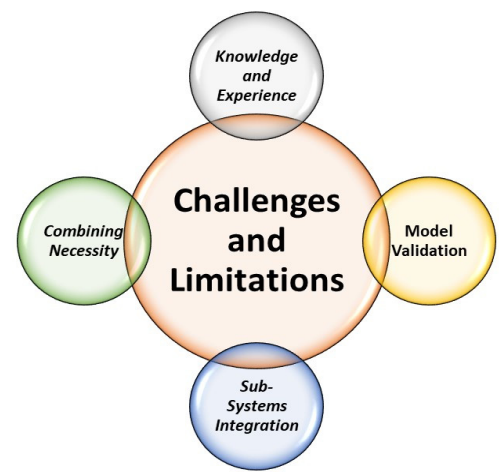

Figure 5. The main challenges and limitations of system dynamic modeling in the water resources applications. 


\subsection{Knowledge and Experience}

In order to establish an integrated system of water management, substantial, multifaceted knowledge, and great experience are required to recognize the relations among different systems. Describing causality relation among many variables and factors is handy and simple using the system dynamics approach. However, this convenience and ease may cause incorrect results due to simplistic models that may be focused on unnecessary and irrelevant details. Consequently, knowledge and experience are required to prevent these cases by performing causality checks, evaluations, and causal relationship assessments. These tests and checks help to ascertain the existence of causal relationships for validation and calibration processes, which considerably increase the reliability of the integrated modeling process.

\subsection{Model Validation}

Validation is extremely relevant in issues relating to water resources that are addressed by mathematical modeling and, in particular, by the approach of SD modeling. Unfortunately, according to Barlas [112], the validation of an SD model is much more difficult than that of a black box model. The reason for this is that the verifying procedure for the internal model frame is largely philosophically and technically complex. Barlas [112] concluded that it is philosophically problematic because it is directly connected and closely linked to the irreplaceable philosophical problem of testing the validity of the scientific argument. Moreover, the issue is technically complicated and this is because there are no recognized validations, such as the tests of statistical hypothesis, which can be used to determine whether or not the model frame is, in reality, close to the problem frame.

\subsection{Subsystems Integration}

While subsystem integration is of great importance in water resource modeling, in most published works, only two or three subsystems are used and treated. Models of efficiently integrated water management systems involve careful consideration of hydrological, ecological, environmental, political, social, economic, and technical parameters and variables in order to shape and cover a number of subsystems that are critical for improving and updating the overall implementation of the integrated modeling process. To be integrated in an evolutionary and holistic manner, some of the critical contemporary issues such as water security, water conflict, water scarcity, water footprint, water sustainability, water pollution control, and conjunctive groundwater and surface water management and wastewater management strategies must be considered in the water resources modeling process.

\subsection{Combining Necessity}

In many water-related problems, the SD modeling approach alone cannot comprehensively describe, analyze. and understand the water system. Accordingly, there is an urgent need for combination with other modeling methods and procedures to expand certainty and confidence when obtaining and measuring parameters, including different features, directions, and patterns of impacting components and building structures in addition to direct procedures to assist the SD modeling. Combining the SD method with other procedures, such as exploratory modeling and analysis, geographic information system, artificial neural network, fuzzy logic, agent-based modeling and simulation, Bayesian network, analytic hierarchy process, impact analysis, game theory, and Delphi method will lead to a stronger framework capable of understanding and modeling hydrology and water management systems more effectively and sufficiently because it can combine its advantages with those of these techniques. 


\section{Concluding Remarks and Directions for Future Work}

Effective agricultural water management includes integrating a number of hydrological, environmental, social, economic, administrative, and political factors into the decision-making process for exploiting, managing, and maintaining available water for agricultural sectors. In this study, a new, comprehensive review of research scientific papers and articles is presented on the application and usage of SD modeling approach in sustainable water management. By examining and analyzing the various applications of SD in hydrological and water systems, we attempted to demonstrate how SD may provide a potentially useful modeling tool for agricultural water management. Issues and problems such as water quality management, water footprints, water conservation policies, regional water resources, environmental water management, drainage water quantity, wastewater reuse, salinity reduction, modeling surface water and groundwater, urban water resources, water scarcity assessment, flood risk, transboundary systems, sustainable management of municipal water, and climate change have been reviewed. Using examples, we addressed the various forms, measures, advantages, and drawbacks of the SD method.

In general, the SD approach is able to provide a complete understanding for relations, influences, and feedbacks among several interrelated subsystems in a hydrological or water system. It is a promising technique to manage emerging complicated issues and relationships while modeling and analyzing hydrological systems. The SD approach can integrate numerical and descriptive techniques, systematically investigate and evaluate complex systems, and realize different internal relations for water resources systems. However, the SD strategy is subject to certain obstacles, issues, and difficulties that need to be tackled and resolved. It requires a thorough understanding of the water management system being studied, and before beginning the modeling process, the modeler or researcher needs to be familiar with the basic parameters and factors that affect the system. In addition, the SD method poses some challenges when dealing with structures and systems with high levels of complexity and changes in different social and environmental conditions. Nevertheless, a number of studies and investigations suggested that the SD modeling methodology be combined with other modeling techniques to resolve these issues and increase performance. Several studies combined the SD modeling approach with artificial neural network, fuzzy logic, geographic information system, agent-based modeling and simulation, Bayesian network, analytic hierarchy method, impact analysis, game theory, exploratory modeling and analysis, and Delphi method. By combining the SD modeling approach with these methods, the findings have improved considerably, and the modeling capacities of the SD approach have expanded, thereby positively impacting water resource systems decision-making, planning, management, and research. Through our analysis, it can be inferred that SD can be used successfully in applications relating to water and agriculture water management economics, policies, and strategies. This will resolve many of the main problems of great importance to agricultural water management, such as groundwater management in agriculture, crop water relations, rainwater harvesting, saline agriculture, farm-level water management, and global climate change.

Author Contributions: A.F.M. developed and wrote the first draft of review, create tables and drew the figures. A.F.M. and A.G.F. participated in technical check and edited the full manuscript. A.G.F. was responsible for conceptualization of draft, work methodology, technical check, and funding source for the manuscript. A.G.F. contributed materials and analysis tools and supervised the work. A.F.M. and A.G.F. discussed the results and commented on the manuscript. All authors have read and agreed to the published version of the manuscript.

Funding: Funding for this research was provided by the National Science Foundation EPSCoR Program under Award No. IIA-1301346 and INFEWS/T1 under Award No. 1739835, the U.S. Bureau of Reclamation/ New Mexico State University Cooperative AgreementR16AC00002, the State of New Mexico Legislature NMWRRI2018, and the New Mexico Agricultural Experiment Station, New Mexico State University.

Acknowledgments: The authors would like to thank three anonymous reviewers for their suggestions and comments that greatly helped in improving the manuscript.

Conflicts of Interest: The authors declare no conflicts of interest. 


\section{References}

1. Food and Agriculture Organization of the United Nations [FAO]. Towards a Water and Food Secure Future: Critical Perspectives for Policy-Makers; FAO: Rome, Italy, 2015.

2. WWAP. The United Nations World Water Development Report 2018: Nature-Based Solutions; UNESCO: Paris, France, 2018.

3. Yang, C.-C.; Chang, L.-C.; Ho, C.-C. Application of system dynamics with impact analysis to solve the problem of water shortages in Taiwan. Water Resour. Manag. 2008, 22, 1561-1577. [CrossRef]

4. Sušnik, J.; Vamvakeridou-Lyroudia, L.S.; Savić, D.A.; Kapelan, Z. Integrated system dynamics modelling for water scarcity assessment: Case study of the kairouan region. Sci. Total Environ. 2012, 440, 290-306. [CrossRef] [PubMed]

5. Li, Y.; Tang, C.; Xu, L.; Ye, S. Using system dynamic model and neural network model to analyse water scarcity in Sudan. In IOP Conference Series: Earth and Environmental Science; IOP: Bristol, UK, 2017.

6. Chen, H.; Chang, Y.-C.; Chen, K.-C. Integrated wetland management: An analysis with group model building based on system dynamics model. J. Environ. Manag. 2014, 146, 309-319. [CrossRef] [PubMed]

7. Balali, H.; Viaggi, D. Applying a system dynamics approach for modeling groundwater dynamics to depletion under different economical and climate change scenarios. Water 2015, 7, 5258-5271. [CrossRef]

8. Chang, Y.-T.; Liu, H.-L.; Bao, A.-M.; Chen, X.; Wang, L. Evaluation of urban water resource security under urban expansion using a system dynamics model. Water Sci. Technol. Water Supply 2015, 15, 1259-1274. [CrossRef]

9. Xin, Z.; Haiyan, F.; Xiaomin, M.; Mingke, Z.; Rui, W. A dynamic water resources management approach in Beijing using system dynamics model, management and service science. In Proceeings of the 2009 International Conference on Management and Service Science, Wuhan, China, 20-22 September 2009.

10. Li, Y.; Hu, C.; Zhao, Y.; Tan, X. Study on sustainable utilization of water resources in Tieling city based on system dynamics approach. In Modeling Risk Management for Resources and Environment in China; Wu, D.D., Zhou, Y., Eds.; Springer: Berlin/Heidelberg, Germany, 2011; pp. 311-319.

11. Guillaume, J.H.A.; Qureshi, M.E.; Jakeman, A.J. A structured analysis of uncertainty surrounding modeled impacts of groundwater-extraction rules. Hydrogeol. J. 2012, 20, 915-932. [CrossRef]

12. Van Emmerik, T.; Li, Z.; Sivapalan, M.; Pande, S.; Kandasamy, J.; Savenije, H.; Chanan, A.; Vigneswaran, S. Socio-hydrologic modeling to understand and mediate the competition for water between agriculture development and environmental health: Murrumbidgee River basin, Australia. Hydrol. Earth Syst. Sci. 2014, 18, 4239. [CrossRef]

13. Ahmad, S.; Simonovic, S.P. Spatial system dynamics: New approach for simulation of water resources systems. J. Comput. Civ. Eng. 2004, 18, 331-340. [CrossRef]

14. Leal Neto, A.C.; Legey, L.F.L.; Gonzalez-Araya, M.C.; Jablonski, S. A system dynamics model for the environmental management of the Sepetiba Bay watershed, Brazil. Environ. Manag. 2006, 38, 879-888. [CrossRef]

15. Madani, K.; Mariño, M.A. System dynamics analysis for managing Iran's Zayandeh-Rud river basin. Water Resour. Manag. 2009, 23, 2163-2187. [CrossRef]

16. Nabavi, E.; Daniell, K.A.; Najafi, H. Boundary matters: The potential of system dynamics to support sustainability? J. Clean Prod. 2017, 140, 312-323. [CrossRef]

17. De Stercke, S.; Mijic, A.; Buytaert, W.; Chaturvedi, V. Modelling the dynamic interactions between London's water and energy systems from an end-use perspective. Appl. Energy 2018, 230, 615-626. [CrossRef]

18. Sterman, J.D. System Dynamics Modeling for Project Management; System Dynamics Group Sloan, School of Managment, Massachusetts Institute of Technology: Cambridge, MA, USA, 1992.

19. Hirsch, G.B.; Levine, R.; Miller, R.L. Using system dynamics modeling to understand the impact of social change initiatives. Am J Community Psychol. 2007, 39, 239-253. [CrossRef] [PubMed]

20. Srijariya, W.; Riewpaiboon, A.; Chaikledkaew, U. System dynamic modeling: An alternative method for budgeting. Value in Health 2008, 11, S115-S123. [CrossRef]

21. Forrester, J.W. Industrial dynamics: A major breakthrough for decision makers. Harv. Bus. Rev. 1958, 36, 37-66.

22. Forrester, J.W. System dynamics-A personal view of the first fifty years. Syst. Dynam. Rev. 2007, 23, 345-358. [CrossRef] 
23. Ibáñez, J.; Contador, J.F.L.; Schnabel, S.; Fernández, M.P.; Valderrama, J.M. A model-based integrated assessment of land degradation by water erosion in a valuable Spanish rangeland. Environ. Model. Softw. 2014, 55, 201-213. [CrossRef]

24. Sehlke, G.; Jacobson, J. System dynamics modeling of transboundary systems: The Bear River Basin model. Ground Water 2005, 43, 722-730. [CrossRef]

25. Sun, Y.; Liu, N.; Shang, J.; Zhang, J. Sustainable utilization of water resources in China: A system dynamics model. J. Clean Prod. 2017, 142, 613-625. [CrossRef]

26. Richardson, G.P. Reflections on the foundations of system dynamics. Syst. Dynam. Rev. 2011, 27, $219-243$. [CrossRef]

27. Khan, S.; Yufeng, L.; Ahmad, A. Analysing complex behaviour of hydrological systems through a system dynamics approach. Environ. Model. Softw. 2009, 24, 1363-1372. [CrossRef]

28. Winz, I.; Brierley, G.; Trowsdale, S. The use of system dynamics simulation in water resources management. Water Resour. Manag. 2009, 23, 1301-1323. [CrossRef]

29. Mirchi, A.; Madani, K.; Watkins, D.; Ahmad, S. Synthesis of system dynamics tools for holistic conceptualization of water resources problems. Water Resour. Manag. 2012, 26, 2421-2442. [CrossRef]

30. Park, S.; Kim, B.J.; Jung, S.Y. Simulation methods of a system dynamics model for efficient operations and planning of capacity expansion of activated-sludge wastewater treatment plants. Proc. Eng. 2014, 70, 1289-1295. [CrossRef]

31. Wa'el A., H.; Memon, F.A.; Savic, D.A. An integrated model to evaluate water-energy-food nexus at a household scale. Environ. Modell Softw. 2017, 93, 366-380.

32. Simonovic, S.P. Tools for water management: One view of the future. Water Int. 2000, 25, 76-88. [CrossRef]

33. Reno, M.D.; Passell, H.D.; Malczynski, L.A.; Peplinski, W.J.; Tidwell, V.C.; Coursey, D.; Brookshire, D. Integrated System Dynamics Toolbox for Water Resources Planning (No. SAND2006-7676); Sandia National Laboratories: Albuquerque, NM, USA; Livermore, CA, USA, 2006.

34. Sterman, J.D. Business Dynamics: Systems Thinking and Modeling for a Complex World; Irwin/McGraw-Hill: Boston, MA, USA, 2000.

35. Richardson, G.P.; Pugh III, A.L. Introduction to System Dynamics Modeling with DYNAMO; MIT Press: Cambridge, MA, USA, 1981.

36. Zomorodian, M.; Lai, S.H.; Homayounfar, M.; Ibrahim, S.; Fatemi, S.E.; El-Shafie, A. (2018). The state-of-the-art system dynamics application in integrated water resources modeling. J. Environ. Manage. 2018, 227, 294-304. [CrossRef]

37. Chen, Z.; Wei, S. Application of system dynamics to water security research. Water Resour. Manag. 2014, 28, 287-300. [CrossRef]

38. Zarghami, S.A.; Gunawan, I.; Schultmann, F. System dynamics modelling process in water sector: A review of research literature. Syst. Res. Behav. Sci. 2018, 35, 776-790. [CrossRef]

39. Kotir, J.H.; Smith, C.; Brown, G.; Marshall, N.; Johnstone, R. A system dynamics simulation model for sustainable water resources management and agricultural development in the Volta River Basin, Ghana. Sci. Total Environ. 2016, 573, 444-457. [CrossRef]

40. Guo, H.C.; Liu, L.; Huang, G.H.; Fuller, G.A.; Zou, R.; Yin, Y.Y. A system dynamics approach for regional environmental planning and management: A study for the Lake Erhai Basin. Environ. Manag. 2001, 61, 93-111. [CrossRef] [PubMed]

41. Turner, B.L.; Tidwell, V.; Fernald, A.; Rivera, J.A.; Rodriguez, S.; Guldan, S.; Ochoa, C.; Hurd, B.; Boykin, K.; Cibils, A. Modeling acequia irrigation systems using system dynamics: Model development, evaluation, and sensitivity analyses to investigate effects of socio-economic and biophysical feedbacks. Sustainability 2016, 8, 1019. [CrossRef]

42. Sušnik, J.; Vamvakeridou-Lyroudia, L.S.; Savić, D.A.; Kapelan, Z. Integrated modelling of a coupled water-agricultural system using system dynamics. J. Water Clim. Change 2013, 4, 209-231. [CrossRef]

43. Langarudi, S.P.; Maxwell, C.M.; Bai, Y.; Hanson, A.; Fernald, A. does socioeconomic feedback matter for water models? Ecol. Econ. 2019, 159, 35-45. [CrossRef]

44. Vezjak, M.; Savsek, T.; Stuhler, E.A. System dynamics of eutrophication processes in lakes. Eur. J. Oper. Res. 1998, 109, 442-451. [CrossRef]

45. Ahmad, S.; Simonovic, S.P. System dynamics modeling of reservoir operations for flood management. J. Comput. Civ. Eng. 2000, 14, 190-198. [CrossRef] 
46. Simonovic, S.P.; Li, L. Methodology for assessment of climate change impacts on large-scale flood protection system. J. Water Resour. Plann. Manag. 2003, 129, 361-371. [CrossRef]

47. Fernald, A.; Tidwell, V.; Rivera, J.; Rodríguez, S.; Guldan, S.; Steele, C.; Ochoa, C.; Hurd, B.; Ortiz, M.; Boykin, K. Modeling sustainability of water, environment, livelihood, and culture in traditional irrigation communities and their linked watersheds. Sustainability 2012, 4, 2998-3022. [CrossRef]

48. Stewart, S.; Valdés, J.; Gastelum, J.; Brookshire, D.; Aparicio, J.; Hidalgo, J.; Velazco, I. A decision support system for demand management in the Rio Conchos Basin, México. In Proceedings of the Hydrology: Science $\mathcal{E}$ Practice for the 21st Century; British Hydrological Society II: London, UK, 2004; pp. 487-494.

49. Leaver, J.D.; Unsworth, C.P. System dynamics modeling of spring behaviour in the Orakeikorako geothermal field, New Zealand. Geothermics 2007, 36, 101-114. [CrossRef]

50. Venkatesan, A.K.; Ahmad, S.; Johnson, W.; Batista, J.R. Salinity reduction and energy conservation in direct and indirect potable water reuse. Desalination 2011, 72, 120-127. [CrossRef]

51. Venkatesan, A.K.; Ahmad, S.; Johnson, W.; Batista, J.R. System dynamics model to forecast salinity load to the Colorado River due to urbanization within the Las Vegas Valley. Sci. Total Environ. 2011, 409, 2616-2625. [CrossRef]

52. Ryu, J.H.; Contor, B.; Johnson, G.; Allen, R.; Tracy, J. System dynamics to sustainable water resources management in the eastern Snake Plain Aquifer under water supply uncertainty. J. Am. Water Resour. Assoc. 2012, 48, 1204-1220. [CrossRef]

53. Hoekema, D.J.; Sridhar, V. A system dynamics model for conjunctive management of water resources in the Snake River Basin. J. Am. Water Resour. Assoc. 2013, 49, 1327-1350. [CrossRef]

54. Gou, S.; Miller, G. A groundwater-soil-plant-atmosphere continuum approach for modelling water stress, uptake, and hydraulic redistribution in phreatophytic vegetation. Ecohydrology 2014, 7, 1029-1041. [CrossRef]

55. Niazi, A.; Prasher, S.; Adamowski, J.; Gleeson, T. A system dynamics model to conserve arid region water resources through aquifer storage and recovery in conjunction with a dam. Water 2014, 6, 2300-2321. [CrossRef]

56. Teegavarapu, R.S.V.; Simonovic, S.P. Simulation of multiple hydropower reservoir operations using system dynamics approach. Water Resour. Manag. 2014, 28, 1937-1958. [CrossRef]

57. Zhu, J.; Wang, X.; Zhang, L.; Cheng, H.; Yang, Z. System dynamics modeling of the influence of the TN/TP concentrations in socioeconomic water on NDVI in shallow lakes. Ecol. Eng. 2015, 76, 27-35. [CrossRef]

58. Sharifi, A.; Kalin, L.; Tajrishy, M. System dynamics approach for hydropower generation assessment in developing watersheds: Case study of karkheh river basin, Iran. J. Hydrol. Eng. 2013, 18, 1007-1017. [CrossRef]

59. Walters, J.P.; Archer, D.W.; Sassenrath, G.F.; Hendrickson, J.R.; Hanson, J.D.; Halloran, J.M.; Alarcon, V.J. Exploring agricultural production systems and their fundamental components with system dynamics modelling. Ecol Model. 2016, 333, 51-65. [CrossRef]

60. Jeong, H.; Adamowski, J. A system dynamics based socio-hydrological model for agricultural wastewater reuse at the watershed scale. Agric. Water Manag. 2016, 171, 89-107. [CrossRef]

61. Mokhtar, A.; Aram, S. Systemic insights into agricultural groundwater management: Case of Firuzabad Plain, Iran. Water Policy 2017, 19, 867-885. [CrossRef]

62. Duran-Encalada, J.A.; Paucar-Caceres, A.; Bandala, E.R.; Wright, G.H. The impact of global climate change on water quantity and quality: A system dynamics approach to the US-Mexican transborder region. Eur. J. Oper. Res. 2017, 256, 567-581. [CrossRef]

63. Wei, S.; Yang, H.; Song, J.; Abbaspour, K.C.; Xu, Z. System dynamics simulation model for assessing socio-economic impacts of different levels of environmental flow allocation in the Weihe River Basin, China. Eur. J. Oper. Res. 2012, 221, 248-262. [CrossRef]

64. Qin, H.-P.; Su, Q.; Khu, S.-T. An integrated model for water management in a rapidly urbanizing catchment. Environ. Model. Softw. 2011, 26, 1502-1514. [CrossRef]

65. Simonovic, S.P.; Ahmad, S. Computer-based model for flood evacuation emergency planning. Nat. Hazard 2005, 34, 25-51. [CrossRef]

66. Hassanzadeh, E.; Elshorbagy, A.; Wheater, H.; Gober, P. Managing water in complex systems: An integrated water resources model for Saskatchewan, Canada. Environ. Model. Softw. 2014, 58, 12-26. [CrossRef] 
67. Zhang, Z.; Lu, W.X.; Zhao, Y.; Song, W.B. Development tendency analysis and evaluation of the water ecological carrying capacity in the Siping area of Jilin Province in China based on system dynamics and analytic hierarchy process. Ecol. Model. 2014, 275, 9-21. [CrossRef]

68. Ahmad, S.; Prashar, D. Evaluating municipal water conservation policies using a dynamic simulation model. Water Resour. Manag. 2010, 24, 3371-3395. [CrossRef]

69. Qaiser, K.; Ahmad, S.; Johnson, W.; Batista, J. Evaluating the impact of water conservation on fate of outdoor water use: A study in an arid region. J. Environ. Manag. 2011, 92, 2061-2068. [CrossRef]

70. Pruyt, E. Small System Dynamics Models for Big Issues: Triple Jump Towards Real-World Dynamic Complexity; TU Delft Library: Delft, The Netherlands, 2013.

71. Simonovic, S.P.; Rajasekaram, V. Integrated analyses of Canada's water resources: A system dynamics approach. Can. Water Resour. J. 2004, 29, 223-250. [CrossRef]

72. Bagheri, A.; Darijani, M.; Asgary, A.; Morid, S. Crisis in urban water systems during the reconstruction period: A system dynamics analysis of alternative policies after the 2003 earthquake in Bam-Iran. Water Resour. Manag. 2010, 24, 2567-2596. [CrossRef]

73. Gastélum, J.; Valdés, J.; Stewart, S. A system dynamics model to evaluate temporary water transfers in the Mexican Conchos basin. Water Resour. Manag. 2010, 24, 1285-1311. [CrossRef]

74. Wang, X.-J.; Zhang, J.-Y.; Liu, J.-F.; Wang, G.-Q.; He, R.-M.; Elmahdi, A.; Elsawah, S. Water resources planning and management based on system dynamics: A case study of Yulin city. Environ. Dev. Sustain. 2011, 13, 331-351. [CrossRef]

75. Zarghami, M.; Akbariyeh, S. System dynamics modeling for complex urban water systems: Application to the city of Tabriz, Iran. Resour. Conserv. Recycl. 2012, 60, 99-106. [CrossRef]

76. Dan, L.; Wei-shuai, C. System dynamics simulation of regional water resources sustainable utilization: A case of Hubei province, China. In Future Communication, Computing, Control and Management; Zhang, Y., Ed.; Springer: Berlin/Heidelberg, Germany, 2012; pp. 311-319.

77. Di Baldassarre, G.; Viglione, A.; Carr, G.; Kuil, L.; Salinas, J.; Blöschl, G. Sociohydrology: Conceptualising human-flood interactions. Hydrol. Earth Syst. Sci. 2013, 17, 3295-3303. [CrossRef]

78. Akhtar, M.K.; Wibe, J.; Simonovic, S.P.; MacGee, J. Integrated assessment model of society-biosphere-climateeconomy-energy system. Environ. Model. Softw. 2013, 49, 1-21. [CrossRef]

79. Rehan, R.; Knight, M.A.; Unger, A.J.A.; Haas, C.T. Development of a system dynamics model for financially sustainable management of municipal water main networks. Water Res. 2013, 47, 7184-7205. [CrossRef]

80. Page, A.; Langarudi, S.P.; Forster-Cox, S.; Fernald, A. A dynamic hydro-socio-technical policy analysis of transboundary desalination development. J. Environ. Account. Manag. 2019, 7, 87-115. [CrossRef]

81. Maxwell, C.M.; Langarudi, S.P.; Fernald, A.G. Simulating a watershed-scale strategy to mitigate drought, flooding, and sediment transport in drylands. Systems 2019, 7, 53. [CrossRef]

82. Liu, G.; Yang, Z.; Chen, B.; Ulgiati, S. Emergy-based dynamic mechanisms of urban development, resource consumption and environmental impacts. Ecol. Model. 2014, 271, 90-102. [CrossRef]

83. Karamouz, M.; Ahmadi, A.; Yazdi, M.S.S.; Ahmadi, B. Economic assessment of water resources management strategies. J. Irrigat. Drain. Eng. 2014, 140, 04013005. [CrossRef]

84. Faezipour, M.; Ferreira, S. Assessing water sustainability related to hospitals using system dynamics modeling. Proc. Comput. Sci. 2014, 36, 27-32. [CrossRef]

85. Elshafei, Y.; Sivapalan, M.; Tonts, M.; Hipsey, M. A prototype framework for models of socio-hydrology: Identification of key feedback loops and parameterization approach. Hydrol. Earth Syst. Sci. 2014, 18, 2141-2166. [CrossRef]

86. Gohari, A.; Madani, K.; Mirchi, A.; Bavani, A.M. System-Dynamics approach to evaluate climate change adaptation strategies for Iran's Zayandeh-Rud Water System. In Proceedings of the World Environmental and Water Resources Congress, Portland, OR, USA, 1-5 June 2014.

87. Nozari, H.; Liaghat, A. Simulation of drainage water quantity and quality using system dynamics. J. Irrigat. Drain. Eng. 2014, 140, 05014007. [CrossRef]

88. Wang, K.; Davies, E.G.; Liu, J. Integrated water resources management and modeling: A case study of Bow river basin, Canada. J. Clean. Prod. 2019, 240, 118242. [CrossRef]

89. Liu, D.; Tian, F.; Lin, M.; Sivapalan, M. A conceptual socio-hydrological model of the co-evolution of humans and water: Case study of the Tarim River basin, western China. Hydrol. Earth Syst. Sci. 2015, 19, 1035-1054. [CrossRef] 
90. Liu, H.; Benoit, G.; Liu, T.; Liu, Y.; Guo, H. An integrated system dynamics model developed for managing lake water quality at the watershed scale. J. Environ. Manag. 2015, 155, 11-23. [CrossRef]

91. Morales-Pinzón, T.; Rieradevall, J.; Gasol, C.M.; Gabarrell, X. Modelling for economic cost and environmental analysis of rainwater harvesting systems. J. Clean. Prod. 2015, 87, 613-626. [CrossRef]

92. Scarborough, H.; Sahin, O.; Porter, M.; Stewart, R. Long-term water supply planning in an Australian coastal city: Dams or desalination? Desalination 2015, 358, 61-68. [CrossRef]

93. Srinivasan, V. Reimagining the past-use of counterfactual trajectories in socio-hydrological modelling: The case of Chennai, India. Hydrol. Earth Syst. Sci. 2015, 19, 785-801. [CrossRef]

94. Rehan, R.; Unger, A.; Knight, M.A.; Haas, C. Strategic water utility management and financial planning using a new system dynamics tool. J. Am. Water Works Assoc. 2015, 107, E22-E36. [CrossRef]

95. Xiong, Y.; Li, J.Z.; Jiang, D.L. Optimization research on supply and demand system for water resources in the Chang-Zhu-Tan urban agglomeration. J. Geogr. Sci. 2015, 25, 1357-1376. [CrossRef]

96. Walters, J.P.; Javernick-Will, A.N. Long-term functionality of rural water services in developing countries: A system dynamics approach to understanding the dynamic interaction of factors. Environ. Sci. Technol. 2015, 49, 5035-5043. [CrossRef]

97. Pande, S.; Savenije, H.H. A sociohydrological model for smallholder farmers in Maharashtra, India. Water Resour. Res. 2016, 52, 1923-1947. [CrossRef]

98. Creighton, J.L.; Langsdale, S. Analysis of Process Issues in Shared Vision Planning Cases; IWR Report 09-R-05; Institute for Water Resources, US Army Corps of Engineers: Alexandria, VA, USA, 2009.

99. Videira, N.; Antunes, P.; Santos, R. Scoping river basin management issues with participatory modelling: The Baixo Guadiana experience. Ecol. Econ. 2009, 68, 965-978. [CrossRef]

100. Beall, A.; Fiedler, F.; Boll, J.; Cosens, B. Sustainable water resource management and participatory system dynamics. Case study: Developing the Palouse basin participatory model. Sustainability 2011, 3, 720-742. [CrossRef]

101. Langsdale, S.; Beall, A.; Carmichael, J.; Cohen, S.; Forster, C. An exploration of water resources futures under climate change using system dynamics modeling. Integrated Assess. 2007, 7, 51-79.

102. Ford, A. Testing the Snake River Explorer. Syst. Dyn. Rev. 1996, 12, 305-329. [CrossRef]

103. Karamouz, M.; Akhbari, M.; Moridi, A.; Kerachian, R. A System dynamics-based conflict resolution model for river water quality management. Iran. J. Environ. Health. Sci. Eng. 2006, 3, 147-160.

104. Butler, C.; Adamowski, J. Empowering marginalized communities in water resources management: Addressing inequitable practices in Participatory Model Building. J. Environ. Manag. 2015, 153, 153-162. [CrossRef]

105. Wang, K.; Davies, E.G.R. A water resources simulation gaming model for the Invitational Drought Tournament. J. Environ. Manag. 2015, 160,167-183. [CrossRef]

106. Kotir, J.H.; Brown, G.; Marshall, N.; Johnstone, R. Systemic feedback modelling for sustainable water resources management and agricultural development: An application of participatory modelling approach in the Volta River Basin. Environ. Model. Softw. 2017, 88, 106-118. [CrossRef]

107. Zomorodian, M.; Lai, S.H.; Homayounfar, M.; Shaliza, I.; Pender, G. Development and application of coupled system dynamics and game theory: A dynamic water conflict resolution method. PLoS ONE 2017, 12, e0188489. [CrossRef]

108. Schwaninger, M. System dynamics and the evolution of the systems movement. Syst. Res. Behav. Sci. 2006, 23, 583-594. [CrossRef]

109. Ahmad, S.S.; Simonovic, S.P. System dynamics and hydrodynamic modelling approaches for spatial and temporal analysis of flood risk. Int. J. River Basin Manag. 2015, 13, 443-461. [CrossRef]

110. Zolfagharian, M.; Romme, A.G.L.; Walrave, B. Why, when, and how to combine system dynamics with other methods: Towards an evidence-based framework. J. Simul. 2018, 12, 98-114. [CrossRef]

111. Wang, G.; Wang, S.; Kang, Q.; Duan, H.; Wang, X.E. An integrated model for simulating and diagnosing the water quality based on the system dynamics and bayesian network. Water Sci. Technol. 2016, 74, 2639-2655. [CrossRef]

112. Barlas, Y. System dynamics: Systemic feedback modeling for policy analysis. System 2007, 1, 59.

113. Lättilä, L.; Hilletofth, P.; Lin, B. Hybrid simulation models-when, why, how? Expert Syst. Appl. 2010, 37, 7969-7975. [CrossRef] 
114. Baki, S.; Koutiva, I.; Makropoulos, C. A hybrid artificial intelligence modelling framework for the simulation of the complete, socio-technical, urban water system. In Proceedings of the 6th International Congress on Environmental Modelling and Software, Leipzig, Germany, 1-5 July 2012.

115. Kwakkel, J.H.; Slinger, J.H. A system dynamics model-based exploratory analysis of salt water intrusion in coastal aquifers. In Proceedings of the 30th International Conference of the System Dynamics Society, St. Gallen, Switzerland, 22-26 July 2012.

116. Kwakkel, J.H.; Timmermans, J.S. Exploratory system dynamics: A directed search for limits to global water use. In Proceedings of the 30th International Conference of the System Dynamics Society, St. Gallen, Switzerland, 22-26 July 2012.

117. Xi, X.; Poh, K.L. A novel integrated decision support tool for sustainable water resources management in Singapore: Synergies between system dynamics and analytic hierarchy process. Water Resour. Manag. 2015, 29, 1329-1350. [CrossRef]

118. Subagadis, Y.H.; Grundmann, J.; Schütze, N.; Schmitz, G.H. An integrated approach to conceptualise hydrological and socio-economic interaction for supporting management decisions of coupled groundwater-agricultural systems. Environ. Earth Sci. 2014, 72, 4917-4933. [CrossRef]

119. Li, Y.-H.; Chen, P.-Y.; Lo, W.-H.; Tung, C.-P. Integrated water resources system dynamics modeling and indicators for sustainable rural community. Paddy Water Environ. 2015, 13, 29-41. [CrossRef]

120. Peterson, K.; Hanson, A.; Roach, J.; Randall, J.; Thomson, B. A Dynamic Statewide Water Budget for New Mexico: Phase III-Future Scenario Implementation; New Mexico Water Resources Research Institute, New Mexico State University: Las Cruces, NM, USA, 2019.

121. Dai, S.; Li, L.; Xu, H.; Pan, X.; Li, X. A system dynamics approach for water resources policy analysis in arid land: A model for Manas River Basin. J. Arid Land 2013, 5, 118-131. [CrossRef]

122. Yang, J.; Lei, K.; Khu, S.; Meng, W. Assessment of water resources carrying capacity for sustainable development based on a system dynamics model: A case study of Tieling City, China. Water Resour. Manag. 2015, 29, 885-899. [CrossRef]

123. Xu, Z.X.; Takeuchi, K.; Ishidaira, H.; Zhang, X.W. Sustainability analysis for yellow river water resources using the system dynamics approach. Water Resour. Manag. 2002, 16, 239-261. [CrossRef]

124. Mereu, S.; Sušnik, J.; Trabucco, A.; Daccache, A.; Vamvakeridou-Lyroudia, L.; Renoldi, S.; Virdis, A.; Savić, D.; Assimacopoulos, D. Operational resilience of reservoirs to climate change, agricultural demand, and tourism: A case study from Sardinia. Sci. Total Environ. 2016, 543, 1028-1038. [CrossRef]

125. Barati, A.A.; Azadi, H.; Scheffran, J. A system dynamics model of smart groundwater governance. Agric. Water Manag. 2019, 221, 502-518. [CrossRef]

126. Garcia, M.; Portney, K.; Islam, S. A question driven socio-hydrological modeling process. Hydrol. Earth Syst. Sci. 2016, 20, 73-92. [CrossRef]

127. Wu, G.; Li, L.; Ahmad, S.; Chen, X.; Pan, X. A dynamic model for vulnerability assessment of regional water resources in arid areas: A case study of Bayingolin, China. Water Resour. Manag. 2013, 27, 3085-3101. [CrossRef]

128. Dawadi, S.; Ahmad, S. Evaluating the impact of demand-side management on water resources under changing climatic conditions and increasing population. J. Environ. Manag. 2013, 114, 261-275. [CrossRef]

129. Xi, X.; Poh, K.L. Using system dynamics for sustainable water resources management in Singapore. Proc. Comput. Sci. 2013, 16, 157-166. [CrossRef]

130. Bai, Y.; Langarudi, S.P.; Fernald, A. Long-term dynamics of acequia population in New Mexico. In Proceedings of the 35th International Conference of the System Dynamics Society, Cambridge, MA, USA, 14 August 2017.

131. Stave, K.A. A system dynamics model to facilitate public understanding of water management options in Las Vegas, Nevada. J. Environ. Manag. 2003, 67, 303-313. [CrossRef]

132. Tidwell, V.C.; Passell, H.D.; Conrad, S.H.; Thomas, R.P. System dynamics modeling for community-based water planning: Application to the Middle Rio Grande. Aquat. Sci. 2004, 66, 357-372. [CrossRef]

133. Bates, G.; Beruvides, M.; Fedler, C.B. System dynamics approach to groundwater storage modeling for basin-scale planning. Water 2019, 11, 1907. [CrossRef]

134. Correia de Araujo, W.; Oliveira Esquerre, K.P.; Sahin, O. Building a system dynamics model to support water management: A case study of the semiarid region in the Brazilian Northeast. Water 2019, 11, 2513. [CrossRef]

135. Wu, R.S.; Liu, J.S.; Chang, S.Y.; Hussain, F. Modeling of mixed crop field water demand and a smart irrigation system. Water 2017, 9, 885. [CrossRef] 
136. Elsayed, H.; Djordjevic, S.; Savic, D. The Nile system dynamics model for water-food-energy nexus assessment. EPiC Series Eng. 2018, 3, 659-667.

137. Vamvakeridou-Lyroudia, L.S.; Savic, D. System dynamics modelling: A tool for participatory simulation of complex water systems within aquastress. Int. Cong. Environ. Model. Softw. 2008, 33, 2025-2028.

138. Lam, N.S.N.; Xu, Y.J.; Liu, K.B.; Dismukes, D.E.; Reams, M.; Pace, R.K.; Cai, H. Understanding the Mississippi River Delta as a coupled natural-human system: Research methods, challenges, and prospects. Water 2018, 10, 1054. [CrossRef]

139. Elmahdi, A.; Malano, H.; Etchells, T. Using system dynamics to model water-reallocation. Environm. 2007, 27, 3-12. [CrossRef]

140. Sušnik, J.; Molina, J.L.; Vamvakeridou-Lyroudia, L.S.; Savić, D.A.; Kapelan, Z. Comparative analysis of system dynamics and object-oriented bayesian networks modelling for water systems management. Water Resour. Manag. 2013, 27, 819-841. [CrossRef]

(C) 2020 by the authors. Licensee MDPI, Basel, Switzerland. This article is an open access article distributed under the terms and conditions of the Creative Commons Attribution (CC BY) license (http://creativecommons.org/licenses/by/4.0/). 